Available online on 15.09.2021 at http://ujpr.org
Universal Journal of Pharmaceutical Research
An International Peer Reviewed Journal
Open access to Pharmaceutical research

\title{
COMPARISON OF LEVELS OF TWENTY CHEMICAL ELEMENTS IN NORMAL THYROID TISSUE AND HYPERTROPHIC THYROID TISSUE Vladimir Zaichick
}

Radionuclide Diagnostics Department, Medical Radiological Research Centre, Obninsk, 249036, Russia.

\section{ABSTRACT}

Background: Goiter can appear as a palpable or visible enlargement of the thyroid gland at the base of the neck. If the goiter is accompanied by hypothyroidism or hyperthyroidism, it may be accompanied by symptoms of the underlying disorder, and nodular goiter (NG) is a health problem of international importance. The aim of this exploratory study was to assess whether there were significant changes in thyroid tissue levels of twenty chemical elements (ChE) $\mathrm{Al}, \mathrm{B}, \mathrm{Ba}, \mathrm{Br}, \mathrm{Ca}, \mathrm{Cl}, \mathrm{Cu}, \mathrm{Fe}, \mathrm{I}, \mathrm{K}, \mathrm{Li}, \mathrm{Mg}, \mathrm{Mn}, \mathrm{Na}$, $\mathrm{P}, \mathrm{S}, \mathrm{Si}, \mathrm{Sr}, \mathrm{V}$, and $\mathrm{Zn}$ are present in the goitrous transformed thyroid.

Methods: Thyroid tissue level of twenty ChE was prospectively evaluated in 46 patients with NG and 105 healthy populations. The measurements were performed using a combination of non-destructive and destructive methods: instrumental neutron activation analysis and inductively coupled plasma atomic emission spectrometry, respectively. Tissue samples were divided into two parts. One was used for morphological study while the other was for $\mathrm{ChE}$ analysis.

Results: It was found that contents of $\mathrm{Al}, \mathrm{B}, \mathrm{Br}, \mathrm{Cl}, \mathrm{Cu}, \mathrm{Fe}, \mathrm{Li}, \mathrm{Mg}, \mathrm{Mn}, \mathrm{Na}, \mathrm{P}, \mathrm{S}, \mathrm{Si}, \mathrm{V}$, and $\mathrm{Zn}$ are significantly higher while the I levels are lower in NG than in normal tissues.

Conclusion: There are considerable changes in ChE contents in goitrous tissue of thyroid. Thus, it is reasonable to assume that the levels of these $\mathrm{ChE}$ in thyroid tissue can be used as NG markers. However, this topic needs additional studies.

Keywords: Biomarkers for goiter diagnosis, chemical elements, inductively coupled plasma atomic emission spectrometry, instrumental neutron activation analysis, intact thyroid thyroid nodular goiter.

Article Info: Received 3 July 2021; Revised 11 August; Accepted 4 September, Available online 15 September 2021

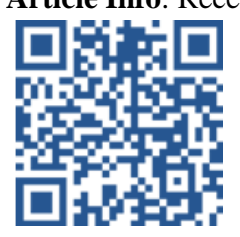

Cite this article-

Zaichick V. Comparison of levels of twenty chemical elements in normal thyroid tissue and hypertrophic thyroid tissue. Universal Journal of Pharmaceutical Research 2021; 6(4):32-42.

DOI: https://doi.org/10.22270/ujpr.v6i4.638

Address for Correspondence

Prof. Dr. V. Zaichick, Radionuclide Diagnostics Department, Medical Radiological Research Centre, Korolyev St. 4,Obninsk 249036, Russia, Tel: +7 4843960289; Fax: +7 4959561440; E-mail: vzaichick@ gmail.com

\section{INTRODUCTION}

At least $10 \%$ of the world's population is affected by goiter detected during examination and palpation and most thyroid lesions are nodular goiter $(\mathrm{NG})^{1}$. However, the use of NG ultrasound can be detected in approximately $70 \%$ of the general population ${ }^{2}$. NG is also known as endemic nodular goitre, simple goitre, nodular hyperplasia, nontoxic uninodular goitre or multinodular goiter ${ }^{3}$. NG are benign lesions; however, during clinical examination, they can mimic malignancies. NG can be hyper functioning, hypofunctioning, and functioning normally. Euthyroid NG is defined as localized enlargement of the thyroid gland without concomitant disruption of thyroid function ${ }^{3}$.

For more than twenty centuries, there has been a prevailing view that $\mathrm{NG}$ is a minor consequence of iodine (I) deficiency. However, NG has been found to be a frequent disease even in those countries and regions where the population is never exposed to I deficiency ${ }^{4}$. Moreover, it was shown that I excess has severe consequences on human health and associated with the presence of thyroidal dysfunctions and autoimmunity, NG and diffuse goiter, benign and malignant tumors of gland ${ }^{5-8}$. It was also demonstrated that besides the iodine deficiency and excess many other dietary, environmental, and occupational factors are associated with the NG incidence ${ }^{9-11}$. Among them a disturbance of evolutionary stable input of many chemical elements (ChE) in human body after industrial revolution plays a significant role in etiology of thyroidal disorders ${ }^{12}$. Besides iodine involved in thyroid function, ChE has basic physiological functions such as maintaining and regulating cell function, regulating genes, activating or inhibiting enzymatic reactions, and regulating membrane function ${ }^{13}$. The essential or toxic (goitogenic, mutagenic, and 
carcinogenic) properties of $\mathrm{ChE}$ depend on the tissuespecific need or tolerance, respectively ${ }^{13}$. Excessive accumulation or an imbalance of the ChE may disturb the cell functions and may result in cellular degeneration, death, benign or malignant transformation $^{13-15}$. In our previous studies the complex of in vivo and in vitro nuclear analytical and related methods was developed and used for the investigation of I and other ChE contents in the normal and pathological thyroid $^{16-22}$. Level of I in the normal thyroid was investigated in relation to age, gender and some nonthyroidal diseases ${ }^{23-24}$. After that, variations of $\mathrm{ChE}$ content with age in the thyroid of males and females were studied and age- and gender-dependence of some ChE was observed ${ }^{25-41}$. Furthermore, a significant difference between some ChE contents in normal and cancerous thyroid was demonstrated ${ }^{42-47}$.

So far, the pathogenesis of NG has to be considered as multifactorial. The present study was performed to clarify the role of twenty $\mathrm{ChE}$ in maintaining thyroid growth and goitrogenesis. With this in mind, our aim was to assess the aluminum ( $\mathrm{Al})$, boron $(\mathrm{B})$, barium $(\mathrm{Ba})$, bromine $(\mathrm{Br})$, calcium $(\mathrm{Ca})$, chlorine $(\mathrm{Cl})$, coper $(\mathrm{Cu})$, iron $(\mathrm{Fe})$, I, potassium $(\mathrm{K})$, lithium $(\mathrm{Li})$, magnesium $(\mathrm{Mg})$, manganese $(\mathrm{Mn})$, sodium $(\mathrm{Na})$, phosphorus (P), sulfur (S), silicon (Si), strontium (Sr), vanadium $(\mathrm{V})$, and zinc $(\mathrm{Zn})$ mass fraction contents in NG tissue using a combination of non-destructive and destructive methods: instrumental neutron activation analysis with high resolution spectrometry of shortlived radionuclides (INAA-SLR) and inductively coupled plasma atomic emission spectrometry (ICPAES), respectively. A further aim was to compare the levels of these twenty $\mathrm{ChE}$ in the goitrous thyroid with those in normal gland of apparently healthy persons.

\section{SUBJECTS AND METHODS}

\section{Samples}

All patients suffered from $\mathrm{NG}(\mathrm{n}=46$, mean age $\mathrm{M} \pm \mathrm{SD}$ was $48 \pm 12$ years, range $30-64$ ) were hospitalized in the Head and Neck Department of the Medical Radiological Research Centre and informed consent was taken from the subjects. Thick-needle puncture biopsy of suspicious nodules of the thyroid was performed for every patient, to permit morphological study of thyroid tissue at these sites and to estimate their ChE contents. For all patients the diagnosis has been confirmed by clinical and morphological results obtained during studies of biopsy and resected materials. Histological conclusion for all thyroidal lesions was the colloid NG. Normal thyroids for the control group samples were removed at necropsy from 105 deceased (mean age $44 \pm 21$ years, range 2-87), who had died suddenly. Samples were obtained within 48 hours after a sudden death. The majority of deaths were due to trauma. Histological examination was used in the control group to match the age criteria, as well as to confirm the absence of micro-nodules and underlying cancer.
Sample preparation, instrumentation and analytical methods

All tissue samples were divided into two portions using a titanium scalpel ${ }^{48}$. One was used for morphological study while the other was intended for ChE analysis. After the samples intended for $\mathrm{ChE}$ analysis were weighed, they were freeze-dried and homogenized ${ }^{49}$. The pounded samples weighing about 5-10 mg (for biopsy) and $100 \mathrm{mg}$ (for resected materials) were used for ChE measurement by INAA-SLR. The samples for INAA-SLR were sealed separately in thin polyethylene films washed beforehand with acetone and rectified alcohol. The sealed samples were placed in labeled polyethylene ampoules. The content of $\mathrm{Br}, \mathrm{Ca}, \mathrm{Cl}, \mathrm{I}, \mathrm{K}$, $\mathrm{Mg}, \mathrm{Mn}$, and $\mathrm{Na}$ were determined by INAA-SLR using a horizontal channel equipped with the pneumatic rabbit system of the WWR-c research nuclear reactor (Branch of Karpov Institute, Obninsk).

After INAA-SLR investigation the thyroid samples were taken out from the polyethylene ampoules and used for ICP-AES. The samples were decomposed in autoclaves. Sample aliquots were used to determine the $\mathrm{Al}, \mathrm{B}, \mathrm{Ba}, \mathrm{Ca}, \mathrm{Cu}, \mathrm{Fe}, \mathrm{K}, \mathrm{Li}, \mathrm{Mg}, \mathrm{Mn}, \mathrm{Na}, \mathrm{P}, \mathrm{S}, \mathrm{Si}, \mathrm{Sr}$, $\mathrm{V}$, and $\mathrm{Zn}$ mass fractions by ICP-AES using the Spectrometer ICAP-61 (Thermo Jarrell Ash, USA). The determination of the $\mathrm{ChE}$ content in aqueous solutions was made by the quantitative method using calibration solutions (High Purity Standards, USA) of 0.5 and $10 \mathrm{mg} / \mathrm{L}$ of each element. The calculations of the $\mathrm{ChE}$ content in the probe were carried out using software of a spectrometer (ThermoSPEC, version 4.1). Information detailing with the NAA-SLR and ICPAES methods used and other details of the analysis were presented in our earlier publications concerning ChE contents in human thyroid, scalp hair, and prostate ${ }^{33,34,50-55}$.

\section{Standards and certified reference material}

To determine contents of the ChE by comparison with a known standard, biological synthetic standards (BSS) prepared from phenol-formaldehyde resins were used ${ }^{56}$. In addition to BSS, aliquots of commercial, chemically pure compounds were also used as standards. Ten subsamples of certified reference material (CRM) IAEA H-4 (animal muscle) and five sub-samples of CRM of the Institute of Nuclear Chemistry and Technology (INCT, Warszawa, Poland) INCT-SBF-4 Soya Bean Flour, INCT-TL-1 Tea Leaves, and INCT-MPH2Mixed Polish Herbs were treated and analyzed in the same conditions that thyroid samples to estimate the precision and accuracy of results. More details about the quality controls of ChE contents in human thyroid were presented in our earlier publications ${ }^{33,34}$.

\section{Computer programs and statistic}

A dedicated computer program for INAA mode optimization was used $^{56}$. All thyroid samples were prepared in duplicate, and mean values of ChE contents were used. Mean values of ChE contents were used in final calculation for the $\mathrm{Br}, \mathrm{Fe}, \mathrm{Rb}$, and $\mathrm{Zn}$ mass fractions measured by two methods. Using Microsoft Office Excel, a summary of the statistics, including, arithmetic mean, standard deviation, standard error of mean, minimum and maximum values, median, percentiles with 0.025 and 0.975 levels was calculated 
for $\mathrm{ChE}$ contents. The difference in the results between two groups (normal and NG) was evaluated by the parametric Student's $t$-test and non-parametric Wilcoxon-Mann-Whitney $U$-test. All studies were approved by the Ethical Committees of the Medical Radiological Research Centre (MRRC), Obninsk (Reference number 115050610007, year2017). All the procedures performed in studies involving human participants were in accordance with the ethical standards of the institutional and/or National research committee and with the 1964 Helsinki declaration and its later amendments, or with comparable ethical standards.

Table 1: Some statistical parameters of Al, B, Ba, Br, Ca, Cl, Cu, Fe, I, K, Li, Mg, Mn, Na, P, S, Si, Sr, V, and Zn mass fraction ( $\mathrm{mg} / \mathrm{kg}$, dry mass basis) in normal and goitrous thyroid.

\begin{tabular}{|c|c|c|c|c|c|c|c|c|c|}
\hline Tissue & Element & Mean & SD & SEM & Min & Max & Median & P 0.025 & P 0.975 \\
\hline \multirow{20}{*}{$\begin{array}{l}\text { Normal } \\
n=105\end{array}$} & $\mathrm{Al}$ & 10.5 & 13.4 & 1.8 & 0.800 & 69.3 & 6.35 & 1.19 & 52.9 \\
\hline & B & 0.476 & 0.434 & 0.058 & 0.200 & 2.30 & 0.300 & 0.200 & 1.73 \\
\hline & $\mathrm{Ba}$ & 1.12 & 1.15 & 0.15 & 0.0480 & 5.00 & 0.680 & 0.0838 & 4.48 \\
\hline & $\mathrm{Br}$ & 14.9 & 11.0 & 1.2 & 1.90 & 54.1 & 11.6 & 2.56 & 49.3 \\
\hline & $\mathrm{Ca}$ & 1682 & 999 & 106 & 373 & 5582 & 1454 & 444 & 4183 \\
\hline & $\mathrm{Cl}$ & 3400 & 1452 & 174 & 1030 & 6000 & 3470 & 1244 & 5869 \\
\hline & $\mathrm{Cu}$ & 4.08 & 1.22 & 0.14 & 0.500 & 7.15 & 4.10 & 1.57 & 6.41 \\
\hline & $\mathrm{Fe}$ & 223 & 95 & 10 & 52.0 & 489 & 210 & 72.8 & 432 \\
\hline & I & 1841 & 1027 & 107 & 114 & 5061 & 1695 & 230 & 4232 \\
\hline & K & 6418 & 2625 & 290 & 1914 & 15293 & 5948 & 2947 & 13285 \\
\hline & $\mathrm{Li}$ & 0.0208 & 0.0155 & 0.0022 & 0.0015 & 0.0977 & 0.0178 & 0.0041 & 0.0487 \\
\hline & $\mathrm{Mg}$ & 296 & 134 & 16 & 66.0 & 930 & 284 & 95.8 & 541 \\
\hline & $\mathrm{Mn}$ & 1.28 & 0.56 & 0.07 & 0.470 & 4.04 & 1.15 & 0.537 & 2.23 \\
\hline & $\mathrm{Na}$ & 6928 & 1730 & 175 & 3686 & 13453 & 6835 & 3974 & 10709 \\
\hline & $\mathrm{P}$ & 4290 & 1578 & 207 & 496 & 8996 & 4221 & 1360 & 7323 \\
\hline & S & 8259 & 2002 & 263 & 644 & 11377 & 8399 & 3662 & 11208 \\
\hline & $\mathrm{Si}$ & 50.8 & 46.9 & 6.2 & 5.70 & 180 & 36.0 & 7.11 & 174 \\
\hline & $\mathrm{Sr}$ & 3.81 & 2.93 & 0.34 & 0.100 & 12.6 & 2.90 & 0.365 & 11.3 \\
\hline & V & 0.102 & 0.039 & 0.005 & 0.0200 & 0.250 & 0.100 & 0.0440 & 0.192 \\
\hline & $\mathrm{Zn}$ & 94.8 & 39.6 & 4.2 & 7.10 & 215 & 88.5 & 34.9 & 196 \\
\hline \multirow{20}{*}{$\begin{array}{l}\text { Goiter } \\
n=46\end{array}$} & $\mathrm{Al}$ & 27.1 & 24.7 & 5.3 & 6.60 & 95.1 & 20.5 & 6.92 & 85.2 \\
\hline & B & 1.71 & 1.19 & 0.26 & 0.90 & 5.00 & 1.00 & 0.95 & 5.00 \\
\hline & $\mathrm{Ba}$ & 1.43 & 1.75 & 0.37 & 0.18 & 8.20 & 0.96 & 0.238 & 5.79 \\
\hline & $\mathrm{Br}$ & 36.3 & 31.3 & 6.99 & 8.0 & 131 & 26.6 & 8.95 & 110 \\
\hline & $\mathrm{Ca}$ & 1422 & 834 & 164 & 288 & 4333 & 1272 & 362 & 3219 \\
\hline & $\mathrm{Cl}$ & 9117 & 3866 & 1223 & 4226 & 16786 & 8259 & 4504 & 15869 \\
\hline & $\mathrm{Cu}$ & 8.51 & 7.15 & 1.60 & 2.90 & 34.8 & 5.95 & 3.00 & 26.2 \\
\hline & $\mathrm{Fe}$ & 337 & 321 & 51 & 62.0 & 1350 & 199 & 65.0 & 1214 \\
\hline & I & 1310 & 1433 & 221 & 29.0 & 8260 & 974 & 107 & 3713 \\
\hline & $\mathrm{K}$ & 6610 & 2233 & 430 & 3353 & 12222 & 6110 & 3395 & 10984 \\
\hline & $\mathrm{Li}$ & 0.0281 & 0.0117 & 0.0030 & 0.0073 & 0.0541 & 0.0259 & 0.0089 & 0.0530 \\
\hline & $\mathrm{Mg}$ & 356 & 119 & 23 & 63.0 & 612 & 371 & 149 & 559 \\
\hline & $\mathrm{Mn}$ & 1.77 & 1.13 & 0.23 & 0.450 & 5.50 & 1.60 & 0.516 & 4.12 \\
\hline & $\mathrm{Na}$ & 11782 & 4342 & 836 & 7229 & 28481 & 10697 & 7279 & 20921 \\
\hline & $\mathrm{P}$ & 5181 & 1798 & 383 & 2890 & 9637 & 5030 & 2919 & 8827 \\
\hline & $\mathrm{S}$ & 10961 & 2091 & 446 & 5591 & 14970 & 10719 & 6824 & 14579 \\
\hline & $\mathrm{Si}$ & 81.3 & 57.3 & 12.5 & 7.80 & 182 & 69.9 & 12.0 & 178 \\
\hline & $\mathrm{Sr}$ & 5.87 & 8.42 & 1.59 & 0.93 & 32.0 & 2.26 & 1.11 & 31.5 \\
\hline & V & 0.152 & 0.074 & 0.016 & 0.043 & 0.370 & 0.150 & 0.056 & 0.310 \\
\hline & $\mathrm{Zn}$ & 120.5 & 50.8 & 7.8 & 47.0 & 264 & 113 & 49.1 & 257 \\
\hline
\end{tabular}

$\mathrm{M}$ - arithmetic mean, SD- standard deviation, SEM - standard error of mean, Min - minimum value, Max- maximum value, P 0.025 - percentile with 0.025 level, P 0.975 - percentile with 0.975 level.

\section{RESULTS}

Table 1 presents certain statistical parameters (arithmetic mean, standard deviation, standard error of mean, minimal and maximal values, median, percentiles with 0.025 and 0.975 levels) of the $\mathrm{Al}, \mathrm{B}$, $\mathrm{Ba}, \mathrm{Br}, \mathrm{Ca}, \mathrm{Cl}, \mathrm{Cu}, \mathrm{Fe}, \mathrm{I}, \mathrm{K}, \mathrm{Li}, \mathrm{Mg}, \mathrm{Mn}, \mathrm{Na}, \mathrm{P}, \mathrm{S}, \mathrm{Si}$, $\mathrm{Sr}, \mathrm{V}$, and $\mathrm{Zn}$ mass fraction in normal and goitrous thyroid. The comparison of our results with published data for $\mathrm{Al}, \mathrm{B}, \mathrm{Ba}, \mathrm{Br}, \mathrm{Ca}, \mathrm{Cl}, \mathrm{Cu}, \mathrm{Fe}, \mathrm{I}, \mathrm{K}, \mathrm{Li}, \mathrm{Mg}, \mathrm{Mn}$, $\mathrm{Na}, \mathrm{P}, \mathrm{S}, \mathrm{Si}, \mathrm{Sr}, \mathrm{V}$, and $\mathrm{Zn}$ mass fraction in normal and goitrous thyroid $^{58-91}$ is shown in Table 2 . The ratios of means and the difference between mean values of $\mathrm{Al}$, $\mathrm{B}, \mathrm{Ba}, \mathrm{Br}, \mathrm{Ca}, \mathrm{Cl}, \mathrm{Cu}, \mathrm{Fe}, \mathrm{I}, \mathrm{K}, \mathrm{Li}, \mathrm{Mg}, \mathrm{Mn}, \mathrm{Na}, \mathrm{P}, \mathrm{S}$, $\mathrm{Si}, \mathrm{Sr}, \mathrm{V}$, and $\mathrm{Zn}$ mass fractions in normal and goitrous thyroid are presented in Table 3 .

\section{DISCUSSION}

Precision and accuracy of results

As was shown before ${ }^{33,34}$, good agreement of our results for the $\mathrm{Al}, \mathrm{B}, \mathrm{Ba}, \mathrm{Br}, \mathrm{Ca}, \mathrm{Cl}, \mathrm{Cu}, \mathrm{Fe}, \mathrm{I}, \mathrm{K}, \mathrm{Mg}$, $\mathrm{Mn}, \mathrm{Na}, \mathrm{P}, \mathrm{S}, \mathrm{Sr}, \mathrm{V}$, and $\mathrm{Zn}$ mass fractions with the certified values of CRM IAEA H-4, INCT-SBF-4, 
INCT-TL-1, and INCT-MPH-2 as well as the similarity of the means of the $\mathrm{Ca}, \mathrm{K}, \mathrm{Mg}, \mathrm{Mn}$, and $\mathrm{Na}$ mass fractions in the normal human thyroid determined by both INAA-SLR and ICP-AES methods demonstrates acceptable precision and accuracy of the results obtained in the study and presented in Tables 1, Table 2 and Table 3 . The mean values and all selected statistical parameters were calculated for twenty $\mathrm{ChE}$ (Al, B, Ba, Br, Ca, Cl, Cu, Fe, I, K, Li, Mg, Mn, Na, P, $\mathrm{S}, \mathrm{Si}, \mathrm{Sr}, \mathrm{V}$, and $\mathrm{Zn}$ ) mass fractions (Table 1). The mass fraction of $\mathrm{Al}, \mathrm{B}, \mathrm{Ba}, \mathrm{Br}, \mathrm{Ca}, \mathrm{Cl}, \mathrm{Cu}, \mathrm{Fe}, \mathrm{I}, \mathrm{K}, \mathrm{Li}$, $\mathrm{Mg}, \mathrm{Mn}, \mathrm{Na}, \mathrm{P}, \mathrm{S}, \mathrm{Si}, \mathrm{Sr}, \mathrm{V}$, and $\mathrm{Zn}$ were measured in all, or a major portion of normal and goitrous tissue samples.

Table 2: Median, minimum and maximum value of means Al, B, Ba, Br, Ca, Cl, Cu, Fe, I, K, Li, Mg, Mn, $\mathrm{Na}$, $\mathrm{P}, \mathrm{S}, \mathrm{Si}, \mathrm{Sr}, \mathrm{V}$, and $\mathrm{Zn}$ contents in the normal and goitrous thyroid according to data from the literature in comparison with our results ( $\mathrm{mg} / \mathbf{k g}$, dry mass basis).

\begin{tabular}{|c|c|c|c|c|c|}
\hline \multirow[t]{2}{*}{ Tissue } & \multirow[t]{2}{*}{ El } & \multicolumn{3}{|c|}{ Published data [Reference] } & \multirow{2}{*}{$\begin{array}{c}\text { This work } \\
\text { M } \pm \text { SD }\end{array}$} \\
\hline & & $\begin{array}{l}\text { Median of means } \\
(\mathbf{n})^{*}\end{array}$ & $\begin{array}{c}\text { Min of means } \\
M \text { or } M \pm S D,(\mathbf{n})^{* *}\end{array}$ & $\begin{array}{c}\text { Max of means } \\
M \text { or } M \pm S D,(\mathbf{n})^{* * *}\end{array}$ & \\
\hline \multirow[t]{20}{*}{ Normal } & $\mathrm{Al}$ & $33.6(12)$ & $0.33(-)^{58}$ & $420(25)^{59}$ & $10.5 \pm 13.4$ \\
\hline & B & $0.151(2)$ & $0.084(3)^{60}$ & $0.46(3)^{60}$ & $0.476 \pm 0.434$ \\
\hline & $\mathrm{Ba}$ & $0.67(7)$ & $0.0084(83)^{61}$ & $\leq 5.0(16)^{62}$ & $1.12 \pm 1.15$ \\
\hline & $\mathrm{Br}$ & $18.1(11)$ & $5.12(44)^{63}$ & $284 \pm 44(14)^{64}$ & $16.3 \pm 11.6$ \\
\hline & $\mathrm{Ca}$ & $1600(17)$ & $840 \pm 240(10)^{65}$ & $3800 \pm 320(29)^{65}$ & $1663 \pm 999$ \\
\hline & $\mathrm{Cl}$ & $6800(5)$ & $804 \pm 80(4)^{66}$ & $8000(-)^{67}$ & $3400 \pm 1452$ \\
\hline & $\mathrm{Cu}$ & $6.0(61)$ & $0.16(83)^{61}$ & $220 \pm 22(10)^{66}$ & $3.93 \pm 1.43$ \\
\hline & $\mathrm{Fe}$ & $252(21)$ & $56(120)^{68}$ & $3360(25)^{59}$ & $223 \pm 95$ \\
\hline & I & $1888(95)$ & $159 \pm 8(23)^{69}$ & $5772 \pm 2708(50)^{70}$ & $1841 \pm 1027$ \\
\hline & $\mathrm{K}$ & $4300(17)$ & $46.4 \pm 4.8(4)^{66}$ & $6090(17)^{62}$ & $6418 \pm 2625$ \\
\hline & $\mathrm{Li}$ & $6.3(2)$ & $0.092(-)^{71}$ & $12.6(180)^{72}$ & $0.0208 \pm 0.0154$ \\
\hline & $\mathrm{Mg}$ & $390(16)$ & $3.5(-)^{58}$ & $1520(20)^{73}$ & $296 \pm 134$ \\
\hline & $\mathrm{Mn}$ & $1.62(40)$ & $0.076(83)^{61}$ & $69.2 \pm 7.2(4)^{66}$ & $1.28 \pm 0.56$ \\
\hline & $\mathrm{Na}$ & $8000(9)$ & $438(-)^{74}$ & $10000 \pm 5000(11)^{75}$ & $6928 \pm 1730$ \\
\hline & $\mathrm{P}$ & $2860(10)$ & $16(7)^{76}$ & $7520(60)^{63}$ & $4290 \pm 1578$ \\
\hline & $\mathrm{S}$ & $11000(3)$ & $4000(-)^{67}$ & $11800(44)^{63}$ & $8259 \pm 2002$ \\
\hline & $\mathrm{Si}$ & $16.0(3)$ & $0.97(-)^{58}$ & $143 \pm 6(40)^{77}$ & $50.8 \pm 46.9$ \\
\hline & $\mathrm{Sr}$ & $0.61(9)$ & $0.055(83)^{61}$ & $46.8 \pm 4.8(4)^{66}$ & $3.81 \pm 2.93$ \\
\hline & $\mathrm{V}$ & $0.065(6)$ & $0.0124(2)^{78}$ & $18 \pm 2(4)^{66}$ & $0.102 \pm 0.039$ \\
\hline & $\mathrm{Zn}$ & $110(56)$ & $2.1(-)^{58}$ & $820 \pm 204(14)^{64}$ & $94.8 \pm 39.7$ \\
\hline \multirow[t]{20}{*}{ Goiter } & $\mathrm{Al}$ & $3.84(6)$ & $2.45(123)^{79}$ & $840(25)^{59}$ & $27.1 \pm 24.7$ \\
\hline & B & - & - & - & $1.71 \pm 1.19$ \\
\hline & $\mathrm{Ba}$ & $4.92(1)$ & $4.92 \pm 4.56(51)^{80}$ & $4.92 \pm 4.56(51)^{80}$ & $1.43 \pm 1.75$ \\
\hline & $\mathrm{Br}$ & $480(4)$ & $9(5)^{81}$ & $777(1)^{82}$ & $36.3 \pm 31.3$ \\
\hline & $\mathrm{Ca}$ & $3168(8)$ & $600(1)^{81}$ & $9200\left(1^{81}\right.$ & $1422 \pm 834$ \\
\hline & $\mathrm{Cl}$ & - & - & - & $9117 \pm 3866$ \\
\hline & $\mathrm{Cu}$ & $10.0(33)$ & $0.84(1)^{72}$ & $353(101)^{\mathbf{8 3}}$ & $8.51 \pm 7.15$ \\
\hline & $\mathrm{Fe}$ & $390(5)$ & $128 \pm 52(13)^{84}$ & $4848 \pm 3056(11)^{64}$ & $337 \pm 321$ \\
\hline & I & $770(44)$ & $52(1)^{85}$ & $2800(4)^{86}$ & $1310 \pm 1433$ \\
\hline & $\mathrm{K}$ & $3725(4)$ & $276(75)^{87}$ & $6030 \pm 620(-)^{88}$ & $6610 \pm 2233$ \\
\hline & $\mathrm{Li}$ & - & - & - & $0.0281 \pm .0 .0117$ \\
\hline & $\mathrm{Mg}$ & $834(4)$ & $588 \pm 388(13)^{84}$ & $1616(70)^{73}$ & $356 \pm 119$ \\
\hline & $\mathrm{Mn}$ & $2.64(21)$ & $0.352(130)^{89}$ & $34.9(101)^{90}$ & $1.77 \pm 1.13$ \\
\hline & $\mathrm{Na}$ & $3360(1)$ & $3360(25)^{59}$ & $3360(25)^{59}$ & $11782 \pm 4342$ \\
\hline & $\mathrm{P}$ & $8200(1)$ & $8200 \pm 280(-)^{88}$ & $8200 \pm 280(-)^{88}$ & $5181 \pm 1798$ \\
\hline & $\mathrm{S}$ & $10300(1)$ & $10300 \pm 340(-)^{88}$ & $10300 \pm 340(-)^{88}$ & $10961 \pm 2091$ \\
\hline & $\mathrm{Si}$ & $64(1)$ & $45(122)^{88}$ & $114(122)^{88}$ & $81.3 \pm 57.3$ \\
\hline & $\mathrm{Sr}$ & $1.45(2)$ & $1.26(25)^{59}$ & $1.64(51)^{80}$ & $5.87 \pm 8.42$ \\
\hline & $\mathrm{V}$ & $3.92(1)$ & $3.92 \pm 8.84(51)^{80}$ & $3.92 \pm 8.84(51)^{80}$ & $0.152 \pm 0.074$ \\
\hline & $\mathrm{Zn}$ & $146(25)$ & $22.4(130)^{89}$ & $1236 \pm 560(2)^{91}$ & $120.5 \pm 50.8$ \\
\hline
\end{tabular}

\section{Comparison with published data}

The means obtained for $\mathrm{Al}, \mathrm{B}, \mathrm{Ba}, \mathrm{Br}, \mathrm{Ca}, \mathrm{Cl}, \mathrm{Cu}, \mathrm{Fe}, \mathrm{I}$, $\mathrm{K}, \mathrm{Mg}, \mathrm{Mn}, \mathrm{Na}, \mathrm{P}, \mathrm{S}, \mathrm{Si}, \mathrm{Sr}, \mathrm{V}$, and $\mathrm{Zn}$ mass fraction, as shown in Table 2, agree well with the medians of mean values reported by other researches for the human thyroid, including samples received from persons who died from different non-thyroid diseases.
The mean obtained for $\mathrm{Li}$ is two orders of magnitude lower than the median of previously reported data. Moreover, it is outside the range of previously reported means. A number of values for $\mathrm{ChE}$ mass fractions were not expressed on a dry mass basis by the authors of the cited references. Hence we calculated these 
values using published data for water $75 \%^{92}$ and ash $4.16 \%$ on dry mass basis ${ }^{93}$ contents in thyroid of adults. In goitrous tissues our results for $\mathrm{Al}, \mathrm{Br}, \mathrm{Ca}, \mathrm{Cu}, \mathrm{Fe}, \mathrm{I}$, $\mathrm{Mn}, \mathrm{Si}$, and $\mathrm{Zn}$ contents were within the range of published means, while means for $\mathrm{K}$ and $\mathrm{Sr}$ were some higher median of previously reported means and also higher the upper level of the range of these means (Table 2). Only one published article on $\mathrm{Ba}^{79}, \mathrm{Na}^{59}, \mathrm{P}^{88}$, $\mathrm{S}^{88}, \mathrm{Si}^{88}$, and $\mathrm{V}^{79}$ contents in the goitrous tissue samples was found in the literature. The mean obtained in the present study for $\mathrm{S}$ content in the goitrous tissue agreed well with early published data, while means for $\mathrm{Ba}$ and $\mathrm{P}$ were some lower and the mean for $\mathrm{Na}$ was some higher. The obtained mean for $\mathrm{V}$ content in the goitrous tissue was more than one order of magnitude lower than the only reported result. No published data referring $\mathrm{B}, \mathrm{Cl}$, and $\mathrm{Li}$ contents of goitrous thyroid tissue were found.

Table 3:Differences between mean values (M+SEM) of $\mathrm{Al}, \mathrm{B}, \mathrm{Ba}, \mathrm{Br}, \mathrm{Ca}, \mathrm{Cl}, \mathrm{Cu}, \mathrm{Fe}, \mathrm{I}, \mathrm{K}, \mathrm{Li}, \mathrm{Mg}, \mathrm{Mn}, \mathrm{Na}, \mathrm{P}, \mathrm{S}$, $\mathrm{Si}, \mathrm{Sr}, \mathrm{V}$, and $\mathrm{Zn}$ mass fraction ( $\mathrm{mg} / \mathrm{kg}$, dry mass basis) in normal and goitrous thyroid.

\begin{tabular}{|c|c|c|c|c|c|}
\hline \multirow[t]{2}{*}{ Element } & \multicolumn{4}{|c|}{ Thyroid tissue } & \multirow{2}{*}{$\begin{array}{c}\text { Ratio } \\
\text { Goiter } \\
\text { to Norm }\end{array}$} \\
\hline & $\begin{array}{l}\text { Norm } \\
n=105\end{array}$ & $\begin{array}{c}\text { Goiter } \\
n=46\end{array}$ & $\begin{array}{c}\text { Student's t-test } \\
p \leq\end{array}$ & $\begin{array}{c}\text { U-test } \\
p\end{array}$ & \\
\hline $\mathrm{Al}$ & $10.5 \pm 1.8$ & $27.1 \pm 5.3$ & 0.0057 & $\leq 0.01$ & 2.58 \\
\hline B & $0.476 \pm 0.058$ & $1.71 \pm 0.26$ & 0.00013 & $\leq \mathbf{0 . 0 1}$ & 3.59 \\
\hline $\mathrm{Ba}$ & $1.12 \pm 0.15$ & $1.43 \pm 0.37$ & 0.446 & $>0.05$ & 1.28 \\
\hline $\mathrm{Br}$ & $14.9 \pm 1.2$ & $36.3 \pm 6.99$ & 0.0067 & $\leq \mathbf{0 . 0 1}$ & 2.44 \\
\hline $\mathrm{Ca}$ & $1682 \pm 106$ & $1422 \pm 164$ & 0.188 & $>0.05$ & 0.84 \\
\hline $\mathrm{Cl}$ & $3400 \pm 174$ & $9117 \pm 1223$ & 0.0011 & $\leq \mathbf{0 . 0 1}$ & 2.68 \\
\hline $\mathrm{Cu}$ & $4.08 \pm 0.14$ & $8.51 \pm 1.60$ & 0.012 & $\leq \mathbf{0 . 0 1}$ & 2.09 \\
\hline $\mathrm{Fe}$ & $223 \pm 10$ & $337 \pm 51$ & 0.034 & $\leq 0.01$ & 1.51 \\
\hline I & $1841 \pm 107$ & $1310 \pm 221$ & 0.035 & $\leq \mathbf{0 . 0 1}$ & 0.71 \\
\hline $\mathrm{K}$ & $6418 \pm 290$ & $6610 \pm 430$ & 0.713 & $>0.05$ & 1.03 \\
\hline $\mathrm{Li}$ & $0.0208 \pm 0.0022$ & $0.0281 \pm 0.0030$ & 0.037 & $\leq \mathbf{0 . 0 1}$ & 1.35 \\
\hline $\mathrm{Mg}$ & $296 \pm 16$ & $356 \pm 23$ & 0.037 & $\leq 0.01$ & 1,20 \\
\hline $\mathrm{Mn}$ & $1.28 \pm 0.07$ & $1.77 \pm 0.23$ & 0.048 & $\leq \mathbf{0 . 0 1}$ & 1.38 \\
\hline $\mathrm{Na}$ & $6928 \pm 175$ & $11782 \pm 836$ & 0.0000041 & $\leq 0.01$ & 1.70 \\
\hline $\mathrm{P}$ & $4290 \pm 207$ & $5181 \pm 383$ & 0.049 & $\leq \mathbf{0 . 0 5}$ & 1.21 \\
\hline S & $8259 \pm 263$ & $10961 \pm 446$ & 0.0000074 & $\leq 0.01$ & 1.33 \\
\hline $\mathrm{Si}$ & $50.8 \pm 6.2$ & $81.3 \pm 12.5$ & 0.037 & $\leq 0.01$ & 1.60 \\
\hline $\mathrm{Sr}$ & $3.81 \pm 0.34$ & $5.87 \pm 1.59$ & 0.216 & $>0.05$ & 1.54 \\
\hline V & $0.102 \pm 0.005$ & $0.152 \pm 0.016$ & 0.0072 & $\leq 0.01$ & 1.49 \\
\hline $\mathrm{Zn}$ & $94.8 \pm 4.2$ & $120.5 \pm 7.8$ & 0.0053 & $\leq 0.01$ & 1.27 \\
\hline
\end{tabular}

The range of means of $\mathrm{Al}, \mathrm{B}, \mathrm{Ba}, \mathrm{Br}, \mathrm{Ca}, \mathrm{Cl}, \mathrm{Cu}, \mathrm{Fe}, \mathrm{I}$, $\mathrm{K}, \mathrm{Li}, \mathrm{Mg}, \mathrm{Mn}, \mathrm{Na}, \mathrm{P}, \mathrm{S}, \mathrm{Si}, \mathrm{Sr}, \mathrm{V}$, and $\mathrm{Zn}$ level reported in the literature for normal and for goitrous thyroid varies widely (Table 2). This can be explained by a dependence of ChE on many factors, including the region of the thyroid, from which the sample was taken, age, gender, ethnicity, gland mass, and the NG stage. Not all these factors were strictly controlled in cited studies. Another and, in our opinion, the main reason for the inter-observer discrepancy can be attributed to the accuracy of the analytical techniques, sample preparation methods, and the inability to take standardized samples from affected tissues. It was insufficient quality control of results in these studies. In many reported papers tissue samples were ashed or dried at high temperature for many hours. In other cases, thyroid samples were treated with solvents (distilled water, ethanol, formalin etc). There is evidence that by use of these sample preparation methods some quantities of certain ChE are lost as a result of this treatment That concern not only such volatile halogen as $\mathrm{Br}$, but also other $\mathrm{ChE}$ investigated in the study ${ }^{94-96}$.

Effect of goitrous transformation on ChE contents From Table 3, it is observed that in goitrous tissue the mass fraction of $\mathrm{Al}, \mathrm{B}, \mathrm{Br}, \mathrm{Cl}$, and $\mathrm{Cu}$ are approximately 2.6, 3.6, 2.4, 2.7, and 2.1 times, respectively, higher and also mass fractions of $\mathrm{Fe}, \mathrm{Li}$, $\mathrm{Mg}, \mathrm{Mn}, \mathrm{Na}, \mathrm{P}, \mathrm{S}, \mathrm{Si}, \mathrm{V}$, and $\mathrm{Zn}$ are almost in $51 \%$, $35 \%, 20 \%, 38 \%, 70 \%, 21 \%, 33 \%, 60 \%, 49 \%$, and $27 \%$ respectively, higher than in normal tissues of the thyroid. In contrast, the mass fraction of I is $29 \%$ significantly lower. Thus, if we accept the $\mathrm{ChE}$ contents in thyroid glands in the control group as a norm, we have to conclude that with a goitrous transformation the levels of $\mathrm{Al}, \mathrm{B}, \mathrm{Br}, \mathrm{Cl}, \mathrm{Cu}, \mathrm{Fe}, \mathrm{Li}$, $\mathrm{Mg}, \mathrm{Mn}, \mathrm{Na}, \mathrm{P}, \mathrm{S}, \mathrm{Si}, \mathrm{V}$, and $\mathrm{Zn}$ in thyroid tissue significantly increased, whereas the level of I some decreased.

Role of $\mathrm{ChE}$ in goitrous transformation of the thyroid

Characteristically, elevated or reduced levels of $\mathrm{ChE}$ observed in goitrous tissues are discussed in terms of their potential role in the initiation and promotion of thyroid goiter. In other words, using the low or high levels of the ChE in goitrous tissues researchers try to determine the goitrogenic role of the deficiency or excess of each $\mathrm{ChE}$ in investigated organ. In our opinion, abnormal levels of many ChE in NG could be and cause, and also effect of goitrous transformation. From the results of such kind studies, it is not always possible to decide whether the measured decrease or increase in $\mathrm{ChE}$ level in pathologically altered tissue is the reason for alterations or vice versa. 


\begin{abstract}
Aluminum
The trace element $\mathrm{Al}$ is not described as essential, because there is no biochemical function directly associated with it. At this point in our knowledge, there is no doubt that $\mathrm{Al}$ overload negatively affects human health, including thyroid function ${ }^{97}$.
\end{abstract}

\section{Boron}

Trace element B is known to influence the activity of many enzymes ${ }^{98}$. Numerous studies have demonstrated beneficial effects of B on human health, including antiinflammatory stimulus-reduces levels of inflammatory biomarkers, such as high-sensitivity $\mathrm{C}$-reactive protein (hs-CRP) and tumor necrosis factor $\alpha(\mathrm{TNF}-\alpha)$; as well as raises levels of antioxidant enzymes, such as superoxide dismutase (SOD), catalase, and glutathione peroxidase ${ }^{98}$. Why $\mathrm{B}$ content in goitrous thyroid is higher than normal level and how an excess of B acts on thyroid are still to be cleared.

\section{Bromine}

This is one of the most abundant and ubiquitous of the recognized trace elements in the biosphere. The inorganic bromide is the ionic form of $\mathrm{Br}$ that exerts therapeutic as well as toxic effects. An enhanced intake of bromide could interfere with the metabolism of I at the whole-body level. In the thyroid gland the biological behavior of bromide is more similar to the biological behavior of iodide ${ }^{99}$. In our previous studies, we found a significant age-related increase of $\mathrm{Br}$ content in human thyroid ${ }^{27,28,0-33}$. Therefore, a goitrogenic and, probably, carcinogenic effect of excessive $\mathrm{Br}$ levels in the thyroid of old females was assumed. On the one hand, elevated levels of $\mathrm{Br}$ in NG tissues, observed in the present study, supports this conclusion. But, on the other hand, bromide compounds, especially potassium bromide $(\mathrm{KBr})$, sodium bromide $(\mathrm{NaBr})$, and ammonium bromide $\left(\mathrm{NH}_{4} \mathrm{Br}\right)$, are frequently used as sedatives in Russia ${ }^{101}$. It may be the reason for elevated levels of $\mathrm{Br}$ in specimens of patients with NG.

\section{Chlorine}

$\mathrm{Cl}$ is a ubiquitous, extracellular electrolyte essential to more than one metabolic pathway. $\mathrm{Cl}$ exists in the ionic form (chloride) in the human body. In the body, it is mostly present as sodium chloride. Therefore, as usual, there is a correlation between $\mathrm{Na}$ and $\mathrm{Cl}$ contents in tissues and fluids of human body. It is well known that $\mathrm{Cl}$ mass fractions in samples depend mainly on the extracellular water volume, including the blood volumes, in tissues ${ }^{102}$. NG tissues are predominantly highly vascularized lesions ${ }^{103}$. Thus, it is possible to speculate that thyroid goiters are characterized by an increase of the mean value of the $\mathrm{Cl}$ mass fraction because the level of goiter vascularization is higher than that in normal thyroid tissue.

\section{Coper}

$\mathrm{Cu}$ is a ubiquitous element in the human body which plays many roles at different levels. Various $\mathrm{Cu}$ enzymes (such as amine oxidase, ceruloplasmin, cytochrome-c oxidase, dopamine-monooxygenase, extracellular superoxide dismutase, lysyl oxidase, peptidyl glycine amidating monoxygenase, $\mathrm{Cu} / \mathrm{Zn}$ superoxide dismutase, and tyrosinase) mediate the effects of $\mathrm{Cu}$ deficiency or excess. $\mathrm{Cu}$ excess can have severe negative impacts. $\mathrm{Cu}$ generates oxygen radicals and many investigators have hypothesized that excess copper might cause cellular injury via an oxidative pathway, giving rise to enhanced lipid peroxidation, thiol oxidation, and, ultimately, DNA damage ${ }^{104}$. Thus, $\mathrm{Cu}$ accumulation in thyroid parenchyma with age may be involved in oxidative stress, dwindling gland function, and increasing risk of goiter/cancer ${ }^{25,26,31,34}$. The significantly elevated level of $\mathrm{Cu}$ in goitrous thyroid, observed in the present study, supports this speculation. However, an overall comprehension of $\mathrm{Cu}$ homeostasis and physiology, which is not yet acquired, is mandatory to establish $\mathrm{Cu}$ exact role in the thyroid goiter etiology and metabolism.

Iron

It is well known that $\mathrm{Fe}$ as a trace element is involved in many very important functions and biochemical reactions of human body. Fe metabolism is therefore very carefully regulated at both a systemic and cellular level ${ }^{104}$. Under the impact of age and multiple environmental factors the Fe metabolism may become dysregulated with attendant accumulation of this metal excess in tissues and organs, including thyroid ${ }^{25,26,29-34}$. Most experimental and epidemiological data support the hypothesis that $\mathrm{Fe}$ overload is a risk factor for benign and malignant tumors ${ }^{106}$. This goitrogenic and oncogenic effect could be explained by an overproduction of ROS and free radicals ${ }^{107}$.

\section{Iodine}

Compared to other soft tissues, the human thyroid gland has higher levels of I, because this element plays an important role in its normal functions, through the production of thyroid hormones (thyroxin and triiodothyronine) which are essential for cellular oxidation, growth, reproduction, and the activity of the central and autonomic nervous system. Goitrous transformation is accompanied by a partial loss of tissue-specific functional features, which leads to a significant reduction in I content associated with functional characteristics of the human thyroid tissue.

\section{Lithium}

The results of lifelong Li-poor nutrition of animals show that $\mathrm{Li}$ is essential to the fauna, and thus, to humans as well ${ }^{108}$. Li-poor nutrition has a negative influence on some enzyme activity, mainly the enzymes of the citrate cycle, glycolysis, and of nitrogen metabolism ${ }^{108}$. On the other hand, $\mathrm{Li}$ is widely used in medicine as a mood-stabilizing drug. Because of the active transport of $\mathrm{Na}^{+} / \mathrm{I}^{-}$ions, $\mathrm{Li}$ is accumulated in the thyroid gland at a concentration 3-4 times higher than that in the plasma. It can inhibit the formation of colloid in thyrocytes, change the structure of thyroglobulin, weaken the iodination of tyrosines, and disrupt their coupling ${ }^{109}$. In addition, it reduces the clearance of free thyroxine in the serum, thereby indirectly reducing the activity of 5-deiodinase type 1 and 2 and reducing the deiodination of these hormones in the liver ${ }^{108}$. All these actions may cause the development of goiter.

\section{Magnesium}

$\mathrm{Mg}$ is abundant in the human body. This element is essential for the functions of more than 300 enzymes (e.g. alkaline phosphatases, ATP-ases, phosphokinases, 
the oxidative phosphorylation pathway). It plays a crucial role in many cell functions such as energy metabolism, protein and DNA syntheses, and cytoskeleton activation. Moreover, $\mathrm{Mg}$ is involved in the thyroid function and plays a central role in determining the clinical picture associated with thyroid disease $^{110}$. The higher Mg levels in NG than do normal tissues, possibly is a result of the high $\mathrm{Mg}$ requirement of growing cells.

\section{Manganese}

Trace element $\mathrm{Mn}$ is a cofactor for numerous enzymes, playing many functional roles in living organisms. The Mn containing enzyme, manganese superoxide dismutase (Mn-SOD), is the principal antioxidant enzyme which neutralizes the toxic effects of reactive oxygen species. It has been speculated that $\mathrm{Mn}$ interferes with thyroid hormone binding, transport, and activity at the tissue level ${ }^{111}$. However, an overall comprehension of $\mathrm{Mn}$ homeostasis and physiology, which is not yet acquired, is mandatory to establish Mn exact role in the thyroid goiter etiology and metabolism.

\section{Sodium}

Knowledge concerning ion regulation in many normal and abnormal cell processes has had a rapid development. It was found, among other regulations, that sodium-calcium exchange is associated with the cytoskeleton and the cell membrane. A hypothesis was eventually established that a wide variety of pathological phenomena ranging from acute cell death to chronic processes, such as neoplasia, all have a common series of cellular reactions ${ }^{112}$. Furthermore, iodide $\left(\mathrm{I}^{-}\right)$, an essential constituent of the thyroid hormones, is actively transported into the thyroid via the $\mathrm{Na}^{+} / \mathrm{I}^{-}$symporter (NIS), a key plasma membrane glycoprotein $^{113}$. In addition, $\mathrm{Na}$ is mainly an extracellular electrolyte and its elevated level in NG might link with a higher goiter vascularization in comparison with the normal thyroid (see Chlorine).

\section{Phosphorus}

$\mathrm{P}$ is necessary for several, various biological roles in the signal transduction of cells and energy exchange of human body. About $80-90 \%$ of $\mathrm{P}$ is founded in teeth and bones in the form of hydroxyapatite. Thyroid hormones play an important role in homeostasis of $\mathrm{Ca}$ and $\mathrm{P}$ levels by their direct action on bone turnover and, as a consequence, $\mathrm{Ca}$ and $\mathrm{P}$ metabolism is frequently disturbed in thyroid dysfunction with a significant increase in the $\mathrm{P}$ serum levels ${ }^{114}$. The elevated level of $\mathrm{P}$ in serum results the higher content of this element in NG tissue, because the goiter vascularization is higher in comparison with the normal thyroid. Besides, the elevated level of thyroid phospholipids in NG is common ${ }^{115}$.

\section{Sulfur}

Proteins contain between 3 and $6 \%$ of sulfur amino acids. Sulfur amino acids contribute substantially to the maintenance and integrity of the cellular systems by influencing the cellular redox state and the capacity to detoxify toxic compounds, free radicals and reactive oxygen species (ROS) ${ }^{115}$. ROS are generated during normal cellular activity and may exist in excess in some pathophysiological conditions, such as inflammation. Therefore exploring fundamental aspects of sulfur metabolism such as the antioxidant effects of sulfur-containing amino acids ${ }^{116}$ may help elucidate the mechanism by which the $\mathrm{S}$ content increases in NG. Thus, it might be assumed that the elevated $S$ level in goitrous thyroid reflects an increase in concentration of ROS in goiter tissue.

Silicon

$\mathrm{Si}$ as a trace element is essential to some specific biological functions in humans ${ }^{118}$. For example, $\mathrm{Si}$ is necessary for the association between cells and one or more macromolecules such as osteonectin, which affects cartilage composition and ultimately cartilage calcification $^{119}$. However, an association between the disorders of thyroid function and the $\mathrm{Si}$ excess in the diets was found ${ }^{120}$. An increase in the thyrotropin (TSH) level in rats was observed after Si-treatment, without statistically significant differences in thyroid hormones concentrations between the test and control groups of animals ${ }^{121}$.

\section{Vanadium}

$\mathrm{V}$ complexes are cofactors for several enzymes that maintaining hemostasis in health and pathology. For example, V compounds normalized blood pressure, ischemia and the metabolism of the thyroid ${ }^{122}$. However, all V compounds have been considered toxic and a goitrogenic and carcinogenic role of $\mathrm{V}$ on the thyroid was proposed ${ }^{123}$. V compounds promote the induction and perpetuation of an inflammatory reaction in the thyroid ${ }^{123}$. Thus, the elevated $\mathrm{V}$ level in thyroid may be a cause of the gland dysfunctions, NG and cancer.

\section{Zinc}

$\mathrm{Zn}$ is active in more than 300 proteins and over 100 DNA-binding proteins, including the tumor suppressor protein $\mathrm{p} 53$, a $\mathrm{Zn}$-binding transcription factor acting as a key regulator of cell growth and survival upon various forms of cellular stress. p53 is mutated in half of human tumors and its activity is tightly regulated by metals and redox mechanisms. On the other hand, excessive intracellular $\mathrm{Zn}$ concentrations may be harmful to normal metabolism of cells ${ }^{124}$. By now much data has been obtained related both to the direct and indirect action of intracellular $\mathrm{Zn}$ on the DNA polymeric organization, replication and lesions, and to its vital role for cell division ${ }^{125,126}$. Other actions of $\mathrm{Zn}$ have been also described. They include its action as a potent anti-apoptotic agent ${ }^{127-131}$. All these facts allowed us to speculate that age-related overload $\mathrm{Zn}$ content in female thyroid, as was found in our previous study $^{25,29,31,33}$, is probably one of the factors in etiology of thyroid goiter and malignant tumors. Therefore, the elevated $\mathrm{Zn}$ level in $\mathrm{NG}$ in comparison with normal level, detected in this study, supports our hypothesis. Our findings show that mass fraction of $\mathrm{Al}, \mathrm{B}, \mathrm{Br}, \mathrm{Cl}$, $\mathrm{Cu}, \mathrm{Fe}, \mathrm{I}, \mathrm{Li}, \mathrm{Mg}, \mathrm{Mn}, \mathrm{Na}, \mathrm{P}, \mathrm{S}, \mathrm{Si}, \mathrm{V}$, and $\mathrm{Zn}$ are significantly different in $\mathrm{NG}$ as compared to normal thyroid tissues (Tables 6). Thus, it is plausible to assume that levels of these ChE in thyroid tissue can be used as NG markers. However, this subjects needs in additional studies. 


\section{Limitations}

This study has several limitations. Firstly, analytical techniques employed in this study measure only twenty $\mathrm{ChE}$ (Al, B, Ba, Br, Ca, Cl, Cu, Fe, I, K, Li, Mg, Mn, $\mathrm{Na}, \mathrm{P}, \mathrm{S}, \mathrm{Si}, \mathrm{Sr}, \mathrm{V}$, and $\mathrm{Zn}$ ) mass fractions. Future studies should be directed toward using other analytical methods which will extend the list of ChE investigated in normal and goitrous thyroid. Secondly, the sample size of NG group was relatively small. It was not allow us to carry out the investigations of $\mathrm{ChE}$ contents in NG group using differentials like gender, histological types of goiter, stage of disease, and dietary habits of healthy persons and patients with NG. Lastly, generalization of our results may be limited to Russian population. Despite these limitations, this study provides evidence on goiter-specific tissue $\mathrm{Al}, \mathrm{B}, \mathrm{Br}$, $\mathrm{Cl}, \mathrm{Cu}, \mathrm{Fe}, \mathrm{I}, \mathrm{Li}, \mathrm{Mg}, \mathrm{Mn}, \mathrm{Na}, \mathrm{P}, \mathrm{S}, \mathrm{Si}, \mathrm{V}$, and $\mathrm{Zn}$ level alteration and shows the necessity to continue $\mathrm{ChE}$ research of goitrous thyroid.

\section{CONCLUSION}

In this work, $\mathrm{ChE}$ measurements in tissue samples from normal and NG colloid thyroid were performed using two useful analytical methods: non-destructive neutron activation analysis with high-resolution short-lived radionuclide spectrometry and inductively coupled plasma atomic emission spectrometry. The combination of these methods has been shown to be a suitable analytical tool for the determination of twenty ChEs (Al, B, Ba, Br, Ca, Cl, Cu, Fe, I, K, Li, Mg, Mn, $\mathrm{Na}, \mathrm{P}, \mathrm{S}, \mathrm{Si}, \mathrm{Sr}$, and $\mathrm{V}$ and $\mathrm{Zn}$ ) in tissue samples from healthy and affected human thyroid, including needle biopsy samples. It was observed that the content of goitrous tissues of $\mathrm{Al}, \mathrm{B}, \mathrm{Br}, \mathrm{Cl}, \mathrm{Cu}, \mathrm{Fe}, \mathrm{Li}, \mathrm{Mg}, \mathrm{Mn}$, $\mathrm{Na}, \mathrm{P}, \mathrm{S}, \mathrm{Si}, \mathrm{V}$ and $\mathrm{Zn}$ increased significantly while the level of I decreased in comparison with normal thyroid tissues. In our opinion, the presented study data strongly suggest that $\mathrm{ChE}$ plays an important role in thyroid health and the etiology of colloidal NG. It was assumed that the differences in ChE levels in affected thyroid tissue could be used as colloidal NG markers.

\section{CONFLICT OF INTEREST}

No conflict of interest associated with this work.

\section{ACKNOWLEDGEMENTS}

The author extends their thanks and appreciation to the Medical Radiological Research Centre, Obninsk, 249036, Russia to provide necessary facilities for this work.

\section{REFERENCES}

1. Carlé A, Krejbjerg A, Laurberg P. Epidemiology of nodular goitre. Influence of iodine intake. Best Pract Res Clin Endocrinol Metab 2014; 28(4):465-479. https://doi.org/10.1016/j.beem.2014.01.001

2. Kant R, Davis A, Verma V. Thyroid nodules: Advances in evaluation and management. Am Fam Physician 2020; 102(5):298-304. PMID: 32866364
3. Hoang VT, Trinh CT. A review of the pathology, diagnosis and management of colloid goitre.Eur Endocrinol. Eur Endocrinol 2020; 16(2):131-135. https://doi.org/10.17925/EE.2020.16.2.131

4. Derwahl M, Studer H. Multinodular goitre: 'much more to it than simply iodine deficiency'. Baillieres Best Pract Res Clin Endocrinol Metab 2000; 14(4):577-600. https://doi.org/10.1053/beem.2000.0104

5. Zaichick V. Iodine excess and thyroid cancer. J Trace Elem Exp Med 1998; 11(4):508-509.

6. Zaichick V, Iljina T. Dietary iodine supplementation effect on the rat thyroid 131I blastomogenic action. In: Die Bedentung der Mengen- und Spurenelemente. 18. Arbeitstangung. Jena: Friedrich-Schiller-Universitat; 1998: 294-306.

7. Kim S, Kwon YS, Kim JY, Hong KH, Park YK. Association between iodine nutrition status and thyroid disease-related hormone in Korean adults: Korean National Health and Nutrition Examination Survey VI (2013-2015). Nutrients 2019; 11(11):2757. https://doi.org/10.3390/nu11112757

8. Vargas-Uricoechea P, Pinzón-Fernández MV, BastidasSánchez BE, Jojoa-Tobar E, Ramírez-Bejarano LE, MurilloPalacios J. Iodine status in the colombian population and the impact of universal salt iodization: a double-edged sword? J Nutr Metab 2019; 6239243.

https://doi.org/10.1155/2019/6239243

9. Stojsavljević A, Rovčanin B, Krstić D, et al. Cadmium as main endocrine disruptor in papillary thyroid carcinoma and the significance of $\mathrm{Cd} / \mathrm{Se}$ ratio for thyroid tissue pathophysiology. J Trace Elem Med Biol 2019; 55:190-195. https://doi.org/10.1016/j.jtemb.2019.06.009

10. Fahim YA, Sharaf NE, Hasani IW, Ragab EA, Abdelhakim HK. Assessment of thyroid function and oxidative stress state in foundry workers exposed to lead. J Health Pollut 2020; 10(27):200903. https://doi.org/10.5696/2156-9614-10.27.200903

11. Liu M, Song J, Jiang Y, et al. A case-control study on the association of mineral elements exposure and thyroid tumor and goiter. Ecotoxicol Environ Saf 2021; 208:111615. https://doi.org/10.1016/j.ecoenv.2020.111615

12. Zaichick V. Medical elementology as a new scientific discipline. J Radioanal Nucl Chem 2006;269:303-309.

13. Moncayo R, Moncayo H. A post-publication analysis of the idealized upper reference value of $2.5 \mathrm{mI} \mathrm{U/L}$ for TSH: Time to support the thyroid axis with magnesium and iron especially in the setting of reproduction medicine. BBA Clin 2017; 7:115-119. https://doi.org/10.1016/j.bbacli.2017.03.003

14. Beyersmann D, Hartwig A. Carcinogenic metal compounds: recent insight into molecular and cellular mechanisms. Arch Toxicol 2008; 82(8):493-512. https://doi.org/10.1007/s00204-008-0313-y

15. Martinez-Zamudio R, Ha HC. Environmental epigenetics in metal exposure. Epigenetics 2011; 6(7):820-827. https://doi.org/10.4161/epi.6.7.16250

16. Zaĭchik VE, RaibukhinYuS, Melnik AD, Cherkashin VI. Neutron-activation analysis in the study of the behavior of iodine in the organism. Med Radiol (Mosk) 1970; 15(1):3336. PMID: 5449249

17. Zaĭchik VE, Matveenko EG, Vtiurin BM, Medvedev VS. Intrathyroid iodine in the diagnosis of thyroid cancer. Vopr Onkol 1982;28(3): 18-24.PMID: 7064415

18. Zaichick V, Tsyb AF, Vtyurin BM. Trace elements and thyroid cancer.Analyst 1995; 120(3):817-821. https://doi.org/10.1039/an9952000817

19. Zaichick VYe, Choporov Yu Ya. Determination of the natural level of human intra-thyroid iodine by instrumental neutron activation analysis. J Radio Nucl Chem 1996; 207(1): 153-161.

20. Zaichick V. In vivo and in vitro application of energydispersive XRF in clinical investigations: experience and the future. J Trace Elem Exp Med 1998; 11(4):509-510. 
21. Zaichick V, Zaichick S. Energy-dispersive X-ray fluorescence of iodine in thyroid punctures biopsy specimens. J Trace Microprobe Tech 1999; 17(2):219-232.

22. Zaichick V. Relevance of, and potentiality for in vivo intrathyroidal iodine determination. Ann N Y Acad Sci 2000; 904:630-632. https://doi.org/10.1111/j.1749-6632.2000.tb06530.x

23. Zaichick V, Zaichick S. Normal human intrathyroidal iodine. Sci Total Environ 1997; 206(1):39-56. https://doi.org/10.1016/s0048-9697(97)00215-5

24. Zaichick V. Human intrathyroidal iodine in health and nonthyroidal disease. In: New aspects of trace element research. London: Smith-Gordon; and Tokyo:Nishimura; 1999:114119 .

25. Zaichick V, Zaichick S. Age-related changes of some trace element contents in intact thyroid of females investigated by energy dispersive X-ray fluorescent analysis. Trends Geriatr Healthc 2017;1(1):31-38. https://doi.org/10.36959/452/579

26. Zaichick V, Zaichick S. Age-related changes of some trace element contents in intact thyroid of males investigated by energy dispersive X-ray fluorescent analysis. MOJ Gerontol Ger 2017; 1(5):00028. https://doi.org/10.15406/mojgg.2017.01.00028

27. Zaichick V, Zaichick S. Age-related changes of $\mathrm{Br}, \mathrm{Ca}, \mathrm{Cl}$, $\mathrm{I}, \mathrm{K}, \mathrm{Mg}, \mathrm{Mn}$, and $\mathrm{Na}$ contents in intact thyroid of females investigated by neutron activation analysis. Curr Updates Aging 2017; 1:5.1.

28. Zaichick V, Zaichick S. Age-related changes of $\mathrm{Br}, \mathrm{Ca}, \mathrm{Cl}$, $\mathrm{I}, \mathrm{K}, \mathrm{Mg}, \mathrm{Mn}$, and $\mathrm{Na}$ contents in intact thyroid of males investigated by neutron activation analysis. J Aging Age Relat Dis 2017; 1(1):1002.

29. Zaichick V, Zaichick S. Age-related changes of Ag, Co, Cr, $\mathrm{Fe}, \mathrm{Hg}, \mathrm{Rb}, \mathrm{Sb}, \mathrm{Sc}, \mathrm{Se}$, and $\mathrm{Zn}$ contents in intact thyroid of females investigated by neutron activation analysis. $\mathbf{J}$ Gerontol Geriatr Med 2017;3:015. https://doi.org/10.24966/GGM-8662/100015

30. Zaichick V, Zaichick S. Age-related changes of Ag, Co, Cr, $\mathrm{Fe}, \mathrm{Hg}, \mathrm{Rb}, \mathrm{Sb}, \mathrm{Sc}, \mathrm{Se}$, and $\mathrm{Zn}$ contents in intact thyroid of males investigated by neutron activation analysis. Curr Trends Biomedical Eng Biosci 2017;4(4):555644. https://doi.org/10.19080/CTBEB.2017.04.555644

31. Zaichick V, Zaichick S. Effect of age on chemical element contents in female thyroid investigated by some nuclear analytical methods. Micro Medicine 2018;6(1):47-61.

32. Zaichick V, Zaichick S. Neutronactivation and X-ray fluorescent analysis in study of association between age and chemical element contents in thyroid of males. Op Acc J Bio Eng Bio Sci 2018;2(4):202-212. https://doi.org/10.32474/OAJBEB.2018.02.000144

33. Zaichick V, Zaichick S. Variation with age of chemical element contents in females' thyroids investigated by neutron activation analysis and inductively coupled plasma atomic emission spectrometry. J Biochem Analyt Stud 2018; 3(1):110. https://doi.org/10.16966/2576-5833.114

34. Zaichick V, Zaichick S. Association between age and twenty chemical element contents in intact thyroid of males. SM Gerontol Geriatr Res 2018; 2(1):1014. https://doi.org/10.36876/smggr.1014

35. Zaichick V, Zaichick S. Associations between age and 50 trace element contents and relationships in intact thyroid of males. Aging Clin Exp Res 2018; 30(9):1059-1070. https://doi.org/10.1007/s40520-018-0906-0

36. Zaichick V, Zaichick S. Possible role of inadequate quantities of intra-thyroidal bromine, rubidium and zinc in the etiology of female subclinical hypothyroidism. EC Gynaecology 2018; 7(3):107-115

37. Zaichick V, Zaichick S. Possible role of inadequate quantities of intra-thyroidal bromine, calcium and magnesium in the etiology of female subclinical hypothyroidism. IntGyn and Women's Health 2018;1(3):IGWHC.MS.ID.000113. https://doi.org/10.32474/IGWHC.2018.01.000113

38. Zaichick V, Zaichick S. Possible role of inadequate quantities of intra-thyroidal cobalt, rubidium and zinc in the etiology of female subclinical hypothyroidism. Womens Health Sci J 2018;2(1):000108.

https://doi.org/10.23880/whsj-16000108

39. Zaichick V, Zaichick S. Association between female subclinical hypothyroidism and inadequate quantities of some intra-thyroidal chemical elements investigated by $\mathrm{X}$ ray fluorescence and neutron activation analysis. Gynaecol Perinatol 2018; 2(4): 340-355.

40. Zaichick V, Zaichick S. Investigation of association between the high risk of female subclinical hypothyroidism and inadequate quantities of twenty intra-thyroidal chemical elements. Clin Res: Gynecol Obstet 2018; 1(1):1-18.

41. Zaichick V, Zaichick S. Investigation of association between the high risk of female subclinical hypothyroidism and inadequate quantities of intra-thyroidal trace elements using neutron activation and inductively coupled plasma mass spectrometry. Acta Scient Med Sci 2018; 2(9):23-37.

42. Zaichick V, Zaichick S. Trace element contents in thyroid cancer investigated by energy dispersive X-ray fluorescent analysis. American J Cancer Res Rev 2018; 2: 5. https://doi.org/10.28933/ajocrr-2017-12-2801

43. Zaichick V, Zaichick S. Trace element contents in thyroid cancer investigated by instrumental neutron activation analysis. J Oncol Res 2018; 2(1):1-13.

44. Zaichick V, Zaichick S. Variation in selected chemical element contents associated with malignant tumors of human thyroid gland. Cancer Studies 2018; 2(1):2. https://doi.org/10.31532/CancerStud.2.1.002

45. Zaichick V, Zaichick S. Twenty chemical element contents in normal and cancerous thyroid. Int $\mathbf{J}$ Hematol Blo Dis 2018;3(2):1-13. https://doi.org/10.1007/s10552-008-9260-4

46. Zaichick V, Zaichick S. Levels of chemical element contents in thyroid as potential biomarkers for cancer diagnosis (a preliminary study). J Cancer Metastasis Treat 2018; 4:60. https://doi.org/10.20517/2394-4722.2018.52

47. Zaichick V, Zaichick S. Fifty trace element contents in normal and cancerous thyroid. Acta Scientific Cancer Biol 2018;2(8):21-38.

48. Zaichick V, Zaichick S. Instrumental effect on the contamination of biomedical samples in the course of sampling. The J Analyt Chem 1996;51(12):1200-1205.

49. Zaichick V, Tsislyak YuV. A simple device for biosample lyophilic drying. Lab Delo 1978; 2: 109-110.

50. Zaichick S, Zaichick V. The effect of age and gender on 37 chemical element contents in scalp hair of healthy humans. Biol Trace Elem Res 2010; 134(1):41-54. https://doi.org/10.1007/s12011-009-8456-0

51. Zaichick V, Nosenko S, Moskvina I. The effect of age on 12 chemical element contents in intact prostate of adult men investigated by inductively coupled plasma atomic emission spectrometry. Biol Trace Elem Res 2012; 147:49-58. https://doi.org/10.1007/s12011-011-9294-4

52. Zaichick V, Zaichick S. NAA-SLR and ICP-AES Application in the assessment of mass fraction of 19 chemical elements in pediatric and young adult prostate glands. Biol Trace Elem Res 2013; 156:357-366. https://doi.org/10.1007/s12011-013-9826-1

53. Zaichick V, Zaichick S. Determination of trace elements in adults and geriatric prostate combining neutron activation with inductively coupled plasma atomic emission spectrometry. Open J Biochem 2014; 1(2):16-33. https://doi.org/10.4236/ajac.2014.511079

54. Zaichick $\mathrm{S}$, Zaichick V. INAA application in the age dynamics assessment of $\mathrm{Br}, \mathrm{Ca}, \mathrm{Cl}, \mathrm{K}, \mathrm{Mg}, \mathrm{Mn}$, and $\mathrm{Na}$ content in the normal human prostate. J Radioanal Nucl Chem 2011;288:197-202. https://doi.org/10.1007/s10967-010-0927-4

55. Zaichick V, Zaichick S. The effect of age on $\mathrm{Br}, \mathrm{Ca}, \mathrm{Cl}, \mathrm{K}$, $\mathrm{Mg}, \mathrm{Mn}$, and $\mathrm{Na}$ mass fraction in pediatric and young adult prostate glands investigated by neutron activation analysis. $\mathbf{J}$ Appl Radiat Isot 2013; 82:145-151. https://doi.org/10.1016/j.apradiso.2013.07.035 
56. Zaichick V. Applications of synthetic reference materials in the Medical Radiological Research Centre. Fresenius J Anal Chem 1995; 352:219-223.https://doi.org/10.1007/BF00322330

57. Korelo AM, Zaichick V. Software to optimize the multielement INAA of medical and environmental samples. In: Activation Analysis in Environment Protection. Dubna, Russia: Joint Institute for Nuclear Research; 1993: 326-332.

58. Kortev AI, Dontsov GI, Lyascheva AP. Bioelements and a human pathology. Sverdlovsk, Russia: Middle-Ural publishing-house; 1972.

59. Kamenev VF. About trace element contents in thyroid of adults. In: Trace Elements in Agriculture and Medicine. Ulan-Ude, Russia: Buryatia publishing-house; 1963:12-16.

60. Tipton IH, Cook MJ. Trace elements in human tissue. Part II. Adult subjects from the United States. Health Phys 1963; 9(2):103-145 https://doi.org/10.1097/00004032-196302000-00002

61. Reitblat MA, Kropachyev AM. Some trace elements in thyroid of the Perm Pricam'ya residents. Proceedings of Perm Medical Institute 1967; 78:157-164.

62. Forssen A. Inorganic elements in the human body. I. Occurrence of $\mathrm{Ba}, \mathrm{Br}, \mathrm{Ca}, \mathrm{Cd}, \mathrm{Cs}, \mathrm{Cu}, \mathrm{K}, \mathrm{Mn}, \mathrm{Ni}, \mathrm{Sn}, \mathrm{Sr}, \mathrm{Y}$ and $\mathrm{Zn}$ in the human body. Ann Med Exp Biol Fenn 1972; 50(3):99-162. PMID: 5081903

63. Zhu H, Wang N, Zhang Y, et al. Element contents in organs and tissues of Chinese adult men. Health Phys 2010; 98(1):61-73. https://doi.org/10.1097/HP.0b013e3181bad921

64. Salimi J, Moosavi K, Vatankhah S, Yaghoobi A. Investigation of heavy trace elements in neoplastic and nonneoplastic human thyroid tissue: A study by proton-induced X-ray emissions. Int J Radiat Res 2004; 1(4): 211-216.

65. Boulyga SF, Zhuk IV, Lomonosova EM, Kanash NV, Bazhanova NN.Determination of microelements in thyroids of the inhabitants of Belarus by neutron activation analysis using the k0-method. J Radioanal Nucl Chem 1997; 222(1-2): 11-14. https://doi.org/10.1007/BF02034238

66. Reddy SB, Charles MJ, Kumar MR, et al. Trace elemental analysis of adenoma and carcinoma thyroid by PIXE method. NuclInstrum Methods Phys Res B: Beam Interactions with Materials and Atoms 2002; 196(3-4): 333-339.

https://www.researchgate.net/publication/223853105_Trace_ele mental_analysis_of_adenoma_and_carcinoma_thyroid_by_P IXE_method

67. Woodard HQ, White DR. The composition of body tissues. Brit J Radiol 1986; 708: 1209-1218. https://doi.org/10.1016/S0168-583X(02)01292-2

68. Ataullachanov IA. Age changes in the content of manganese, cobalt, copper, zinc and iron in the endocrine glands of women. Probl Endocrinol (Mosk) 1969; 15(2): 98-102. PMID: 5807109

69. Neümark II, Timoshnikov VM. Development of thyroid cancer in persons living in the endemic goiter area. Probl Endokrinol (Mosk) 1978;24(3):28-32.PMID: 674124

70. Zabala J, Carrion N, Murillo M, et al. Determination of normal human intrathyroidal iodine in Caracas population. $\mathbf{J}$ Trace Elem Med Biol 2009; 23(1): 9-14. https://doi.org/10.1016/j.jtemb.2008.11.002

71. Zakutinsky DK, ParfyenovYuD, Selivanova LN. Handbook of the toxicology of radioactive isotopes. Moscow: State Publishing House of Medical Literature; 1962.

72. Remiz AM. Endemic goiter and trace elements in KabardinoBalkaria ASSR. In: The $5^{\text {th }}$ meeting of chirurgeons of Northern Caucasia. Rostov-on-Don: 1962:276-278.

73. Li AA. Level of some macro- and trace element contents in blood and thyroid of patients with endemic goiter in Kalinin region. $\mathrm{PhD}$ thesis. Kalinin, Russia: Kalinin medical institute; 1973.

74. Boulyga SF, Becker JS, Malenchenko AF, Dietze HJ. Application of ICP-MS for multielement analysis in small sample amounts of pathological thyroid tissue. Microchimica Acta 2000;134(3-4):215-222.

75. Soman SD Joseph KT, Raut SJ, Mulay CD, Parameshwaran M, Panday VK. Studies of major and trace element content in human tissues. Health Phys 1970; 19(5):641-656.
76. Novikov GV, Vlasova ZA. Some organism functions in connection with the iodine content in diet and feed of experimental animals. In: Role of Trace Elements in Agriculture and Medicine. Leningrad: Nauka; 1970;2:6-7.

77. Bredikhin LM, Soroka VP. Trace element metabolism in patients with goiter during therapy. Vrach Delo. 1969; 51(6): 81-84. PMID: 5821671

78. Byrne AR. Vanadium in foods and in human body fluids and tissues. Sci Total Environ 1978; 10: 17-30. https://doi.org/10.1016/0048-9697(78)90046-3

79. Ianchur NM, Elenevskaia NS, But-Gusaim AM, Nikhamkin LI. The content of manganese, aluminum, copper and zinc in the blood and the thyroid gland of patients with goiter. Klin Khir1967; 4:27-30. PMID: 4888317

80. Antonova MV, Elinova VG, Voitekhovskaya YaV. Some trace element contents in thyroid and water in endemic goiter region. Zdravookhranenie BSSR 1966; 9:42-44.

81. Maeda K, Yokode Y, Sasa Y, Kusuyama H, Uda M. Multielemental analysis of human thyroid glands using particle induced X-ray emission (PIXE). Nucl Instrum Methods Phys Res B 1987; 22(1-3):188-190. https://doi.org/10.1016/0168-583X(87)90323-5

82. Turetskaia ES. Studies on goitrous thyroid glands for iodine and bromine content. Probl Endokrinol Gormonoter 1961;7(2):75-80. PMID: 13778682

83. Aingorn NM, Chartorizhskaya NA. Comparative characteristics of trace element contents under thyroid disorders. In: Trace Elements in Agriculture and Medicine. Ulan-Ude, Russia: Buryatiapublishing-house; 1966:113-114.

84. Kaya G, Avci H, Akdeniz I, Yaman M. Determination of trace and minor metals in benign and malign human thyroid tissues. Asian J Chem 2009; 21(7):5718-5726.

85. Dimitriadou A, Suvanik R, Fraser TR, Pearson J.D. Endemic goiter in Thailand. A study contrasting these iodine-deficient goiters with sporadic non-toxic goiters seen in London. J Endocrinol 1966; 34(1):23-39. https://doi.org/10.1677/joe.0.0340023

86. Braasch JW, Abbert A, Keating FR, Black BM. A note of the iodinated constituents of normal thyroids and of exophthalmic goiters. J Clin Endocrinol Metab 1955; 15(4):732-738. https://doi.org/10.1210/jcem-15-6-732

87. Bolkvadze AI. Contents of electrolytes (K, Na, Ca, I and F) in thyroid and blood under different forms of thyroid pathology. PhD thesis. Tbilisi: Tbilisi medical institute; 1970.

88. Borodin AE, Sokolova II, Gogolev VG, Makarova MYa. About goitrous thyroid chemical composition. In: Goiter in Amur region. Blagoveshchensk: Khabarovsk publishinghouse; 1967:21-29.

89. Stojsavljević A, Rovčanin B, Krstić D, et al. Evaluation of trace metals in thyroid tissues: Comparative analysis with benign and malignant thyroid diseases. Ecotoxicol Environ Saf 2019;183:109479. https://doi.org/10.1016/j.ecoenv.2019.109479

90. Petrov IC, Alyab'ev GA, Dmitrichenko MM. Contents of iodine, manganese, and cobalt in thyroid and blood in the local residents and migrants of Irkutsk region. In: Trace elements in agriculture and medicine. Ulan-Ude, Russia: Buryatia publishing-house; 1968:648-651.

91. Zagrodzki P, Nicol F, Arthur JR, et al. Selenoenzymes, laboratory parameters, and trace elements in different types of thyroid tumor. Biol Trace Elem Res 2010; 134(1): 25-40. https://doi.org/10.1007/s12011-009-8454-2

92. Katoh Y, Sato T, Yamamoto Y. Determination of multielement concentrations in normal human organs from the Japanese. Biol Trace Elem Res 2002; 90(1-3): 57-70. https://doi.org/10.1385/BTER:90:1-3:57

93. Schroeder HA, Tipton IH, Nason AP. Trace metals in man: strontium and barium. J Chron Dis 1972; 25(9):491-517. https://doi.org/10.1016/0021-9681(72)90150-6

94. Zaichick V. Sampling, sample storage and preparation of biomaterials for INAA in clinical medicine, occupational and environmental health. In: Harmonization of health-related 
environmental measurements using nuclear and isotopic techniques. Vienna: IAEA; 1997:123-133.

95. Zaichick V, Zaichick S. A search for losses of chemical elements during freeze-drying of biological materials. J Radioanal Nucl Chem 1997; 218(2):249-253. https://doi.org/10.1007/BF02039345

96. Zaichick V. Losses of chemical elements in biological samples under the dry aching process. Trace Elements in Medicine 2004; 5(3):17-22.

97. Krewski D, Yokel RA, Nieboer E, et al. Human health risk assessment for aluminium, aluminium oxide, and aluminium hydroxide. J Toxicol Environ Health Part B 2007; 10:1-269. https://doi.org/10.1080/10937400701597766

98. Naghii MR, Mofid M, Asgari AR, Hedayati M, Daneshpour MS. Comparative effects of daily and weekly boron supplementation on plasma steroid hormones and proinflammatory cytokines. J Trace Elem Med Biol 2011; 25:54-58. https://doi.org/10.1016/j.jtemb.2010.10.001

99. Pizzorno L. Nothing boring about boron. Integr Med (Encinitas) 2015; 14:35-48. PMID: 26770156

100. Pavelka S. Radiometric determination of thyrotoxic effects of some xenobiotics. Rad Applic 2016; 1(2):155-158. https://doi.org/10.21175/RadJ.2016.02.029

101. Maschkovsky MD. The sedatives. In: The Medicaments. $15^{\text {th }}$ ed. Moscow: Novaya Volna; 2005:72-86.

102. Zaichick V. X-ray fluorescence analysis of bromine for the estimation of extracellular water. J Appl Radiat Isot 1998; 49(12): 1165-1169. https://doi.org/10.1016/s0969-8043(97)10118-x

103. Lyshchik A, Moses R, Barnes SI, et al. Quantitative analysis of tumor vascularity in benign and malignant solid thyroid nodules. J Ultrasound Med 2007; 26(6): 837-846. https://doi.org/10.7863/jum.2007.26.6.837

104. Li Y, Trush MA. DNA damage resulting from the oxidation of hydroquinone by copper: role for a $\mathrm{Cu}(\mathrm{II}) / \mathrm{Cu}(\mathrm{I})$ redox cycle and reactive oxygen generation. Carcinogenesis 1993; 14(7): 1303-1311. https://doi.org/10.1093/carcin/14.7.1303

105. Torti SV, Manz DH, Paul BT, Blanchette- Farra N, Torti FM. Iron and Cancer. Annu Rev Nutr 2018; 38: 97-125. https://doi.org/10.1146/annurev-nutr-082117-051732

106. Selby JV, Friedman GD. Epidemiologic evidence of an association between body iron stores and risk of cancer. Int $\mathbf{J}$ Cancer 1988; 41: 677-682. https://doi.org/10.1002/ijc.2910410507

107. Meneghini R. Iron homeostasis, oxidative stress, and DNA damage. Free Radic Biol Med 1997; 23: 783-792. https://doi.org/10.1016/s0891-5849(97)00016-6

108. Anke M, Arnhold W, Schäfer U, Müller R. Recent progress in exploring the essentiality of the ultratrace element lithium to the nutrition of animals and man. Biomed Res Trace Elem 2005; 16(3): 169-176. https://doi.org/10.11299/brte.16.169

109. Czarnywojtek A, Zgorzalewicz-Stachowiak M, Czarnocka B, et al. Effect of lithium carbonate on the function of the thyroid gland: mechanism of action and clinical implications. J Physiol Pharmacol 2020; 71(2): 191-199. https://doi.org/10.26402/jpp.2020.2.03

110. Chandra A.K. Effects of magnesium on cytomorphology and enzyme activities in thyroid of rats. Indian J Exp Biol 2014; 52: 787-792. PMID: 25141541

111. Soldin OP, Aschner M. Effects of manganese on thyroid hormone homeostasis. Neurotoxicol 2007; 28: 951-956. https://doi.org/10.1016/j.neuro.2007.05.003

112. Trump BF, Berezesky IK, Phelps PC. Sodium and calcium regulation and the role of the cytoskeleton in the pathogenesis of disease: A review and hypothesis. Scan Electron Microsc 1981; (Pt 2): 434-454. PMID: 7034180

113. Ravera S, Reyna-Neyra A, Ferrandino G, Amzel M, Carrasco $\mathrm{N}$, The sodium/iodide symporter (NIS): Molecular physiology and preclinical and clinical applications. Annu Rev Physiol 2017; 79: 261-289. https://doi.org/10.1146/annurev-physiol-022516-034125

114. Ashmaik AS, Gabra HM, Elzein AOM. Shrif NEMA, Hassan EE. Assessment of serum levels of calcium and phosphorous in Sudanese patients with hypothyroidism. Asian J Biomed Pharm 2013; 3(25): 21-26.

115. Stelmach H, Mośko P, Jaroszewicz L, Piotrowski Z, Puchalski Z. Phospholipids of human thyroid gland. Acta Physiol Hung 1993; 81(3): 263-267. PMID: 8197881

116. Townsend DM, Tew KD, Tapiero H. Sulfur containing amino acids and human disease. Biomed Pharmacother 2004; 58: 47-55. https://doi.org/10.1016/j.biopha.2003.11.005

117. Atmaca G. Antioxidant effects of sulfur-containing amino acids. Yonsei Med J 2004; 45: 776-788. https://doi.org/10.3349/ymj.2004.45.5.776

118. Pérez-Granados AM, Vaquero MP. Silicon, aluminium, arsenic and lithium: essentiality and human health implications. J Nutr Health Aging 2002; 6(2): 154-162. PMID: 12166372

119. Nielsen FH. Nutritional requirements for boron, silicon, vanadium, nickel, and arsenic: current knowledge and speculation. FASEB J 1991; 5(12): 2661-2667. PMID: 1916090

120. Semenov VD, Suslikov VL. Role of nutrition in the development of functional shifts in the thyroid. Vopr Pitan 1983; 3: 65-68. PMID: 6225246

121. Najda J, Gmiński J, Drózdz M, Zych F. The influence of inorganic silicon $(\mathrm{Si})$ on pituitary-thyroid axis. Biol Trace Elem Res 1993; 37(2-3): 101-106. https://doi.org/10.1007/BF02783785

122. Gruzewska K, Michno A, Pawelczyk T, Bielarczyk H. Essentiality and toxicity of vanadium supplements in health and pathology. J Physiol Pharmacol 2014; 65(5): 603-611. PMID: 25371519

123. Fallahi $\mathrm{P}$, Foddis $\mathrm{R}$, Elia $\mathrm{G}$, et al. Vanadium pentoxide induces the secretion of CXCL9 and CXCL10 chemokines in thyroid cells. Oncol Rep 2018; 39(5): 2422-2426. https://doi.org/10.3892/or.2018.6307

124. Bozym RA, Chimienti F, Giblin LJ, et al. Free zinc ions outside a narrow concentration range are toxic to a variety of cells in vitro. Exp Biol Med (Maywood) 2010; 235(6): 741750. https://doi.org/10.1258/ebm.2010.009258

125. Matusik RJ, Kreis C, McNicol P, et al. Regulation of prostatic genes: role of androgens and zinc in gene expression. Biochem Cell Biol 1986; 64: 601-607. https://doi.org/10.1139/o86-083

126. Blok LJ, Grossmann ME, Perry JE, Tindall DJ. Characterization of an early growth response gene, which encodes a zinc finger transcription factor, potentially involved in cell cycle regulation. Mol Endocrinol 1995; 9(11): 1610-1620.https://doi.org/10.1210/mend.9.11.8584037

127. Zezerov EG. Hormonal and molecular biological factors in pathogenesis of prostate cancer. Vopr Onkol 2001; 47(2):174-181.PMID: 11383453

128. Truong-Tran AQ, Ho LH, Chai F, Zalewski PD. Cellular zinc fluxes and the regulation of apoptosis/gene-directed cell death. J Nutr 2000; 130(5S Suppl): 1459S-1466S. https://doi.org/10.1093/jn/130.5.1459S

129. Kontargiris E, Vadalouka A, Ragos V, KalfakakouV. Zinc inhibits apoptosis and maintains NEP downregulation, induced by Ropivacaine, in HaCaT cells. Biol Trace Elem Res 2012; 150: 460-466. https://doi.org/10.1007/s12011-012-9492-8

130. Liang D, Yang M, Guo B, et al. Zinc inhibits $\mathrm{H}_{2} \mathrm{O}_{2}$-induced MC3T3-E1 cells apoptosis via MAPK and PI3K/AKT pathways. Biol Trace Elem Res 2012; 148: 420-429. https://doi.org/10.1007/s12011-012-9387-8

131. Zhang X, Liang D, Guo B, Yang L, Wang L, Ma J. Zinc inhibits high glucose-induced apoptosis in peritoneal mesothelial cells. Biol Trace Elem Res 2012; 150: 424-432. https://doi.org/10.1007/s12011-012-9473-y 